\title{
Faktor Yang Mempengaruhi Pemanfaatan Posyandu Lansia
} di Imogiri Kabupaten Bantul

\author{
Hendri Purwadi ${ }^{1}$, Hamam Hadi² ${ }^{2}$ M.Nur Hasan³ \\ 1, 2, 3Sekolah Tinggi IImu Kesehatan Alma Ata Yogyakarta \\ Jalan Ringroad Barat Daya No 1 Tamantirto, Kasihan, Bantul Yogyakarta
}

\begin{abstract}
Abstrak
Posyandu lansia adalah salah satu cara untuk mengantisipasi perubahan degeneratif yang terjadi pada lansia. Jumlah kunjungan ke posyandu lansia di Dusun Karangkulon 2010, rata-rata 60 lansia dari 160 lansia yang terdaftar. Penelitian observasional dengan disain cross sectional ini bertujuan untuk mengetahui faktor yang berpengaruh terhadap pemanfaatan posyandu lansia. Sampel diambil dengan teknik total sampling pada 160 populasi lansia di Dusun Karangkulon. Pengambilan data menggunakan kuesioner dan wawancara. Analisis menggunakan uji chi square dan regresi logistik. Hasil uji chi square menujukkan variabel jenis kelamin $(0,000)$, status perkawinan $(p=0,018)$, persepsi sehat sakit $(p=0,000)$, persepsi kualitas pelayanan $(p=0,000)$ ada pengaruh terhadap pemanfaatan posyandu lansia. Sedangkan variabel umur $(0,774)$, pendidikan $(p=0,059)$, pekerjaan $(p=1)$, dukungan refrence group $(0,865)$ tidak ada pengaruh terhadap pemanfaatan posyandu lansia. Hasil uji Regresi logistik menunjukkan bahwa variabel yang paling dominan $(p=0,025)$ berpengaruh terhadap pemanfaatan posyandu lansia adalah persepsi kualitas pelayanan posyandu. Kesimpulan: Ada pengaruh signifikan jenis kelamin, status perkawinan, persepsi sehat sakit dan persepsi kualitas pelayanan terhadap pemanfaatan posyandu lansia. Disarankan kader dan petugas kesehatan untuk meningkatkan kualitas pelayanan dan penyuluhan posyandu lansia.
\end{abstract}

Kata Kunci: pemanfaatan pelayanan, posyandu, lansia

Info Artikel:

Artikel dikirim pada 19 Agustus 2013

Artikel diterima pada 19 Agustus 2013

\section{PENDAHULUAN}

Perkembangan ilmu pengetahuan dan teknologi memberikan dampak positif terhadap kesejahteraan dan kesehatan, salah satunya terlihat dari meningkatnya usia harapan hidup (life expentacy rate). Peningkatan usia harapan hidup menimbulkan peningkatan jumlah lanjut usia (lansia) di dunia. Lanjut usia adalah seseorang yang berumur 60 tahun atau lebih (Nugroho 2010). Peningkatan ini dapat dilihat dari jumlah lansia di dunia pada periode tahun 19501970 dengan periode 1970-2000. Pertambahan penduduk dunia tahun $1950-1970$ sebesar $46,1 \%$ dengan usia 60 tahun mencapai 54,7 juta jiwa, sedangkan yang berusia 70 tahun sebesar 56,0 juta jiwa. Tahun 1970-2000 mengalami peningkatan pertambahan penduduk sebesar $78,8 \%$ dengan usia 60 tahun mencapai 101,1 juta jiwa sedangkan usia 70 tahun mencapai 118,7 juta jiwa. Jumlah lansia dengan usia rata-rata 60 tahun pada tahun 2025 diperkirakan akan mencapai 1,2 milyar jiwa (Nugroho, 2010). Sedangkan berdasarkan hasil pencacahan sensus penduduk 2010, jumlah penduduk Indonesia adalah sebesar 237.556.363 jiwa atau sekitar 8,48\% dari keseluruhan jumlah penduduk Indonesia. ( $\underline{w w w}$. id.wikipedia.org).

Meningkatnya jumlah lansia perlu terus diantisipasi karena akan membawa implikasi luas dalam kehidupan keluarga, masyarakat, dan negara. Karena itu, lansia perlu mendapatkan perhatian dalam pembangunan nasional. Diperlukan peningkatan jenis dan kualitas pelayanan kesehatan dan keperawatan baik yang dilakukan oleh lansia itu sendiri maupun oleh keluarga atau lembaga lain seperti pusat santunan dalam keluarga (pusaka), posyandu lansia, panti tresna wrehda maupun posyandu lansia. Posyandu adalah wadah kegiatan dari masyarakat dan untuk masyarakat yang didukung kerjasama lintas sektoral.Puskesmas memberi dukungan dan pembinaan teknis. Kegiatan yang ada di posyandu 
meliputi kegiatan preventif,promotif, kuratif dan rehabilitatif. Kegiatan tersebut yaitu penyuluhan kesehatan, pengukuran tekanan darah, pemeriksaan fisik kesehatan lansia, pengobatan dan kesegaran jasmani (Departemen Kesehatan RI, 2003).

Pentingnya penelitian ini dilakukan karena belum dimanfaatkannya posyandu lansia yang ada secara optimal. Beberapa faktor yang berpengruh terhadap pemanfaatan pelayanan kesehatan menurut Notoatmodjo (2003) antara lain adalah persepsi atau konsep masyarakat tentang sehat dan sakit, persepi maysarakat tentang kualitas pelayanan, struktur sosial dan juga adanya masyarakat sebagai referensi (refrence group).

Jumlah lansia yang terdata di posyandu lansia Dusun Karangkulon selama tahun 2010 adalah 160 orang yang terdiri dari 65 lansia laki-laki dan 95 lansia perempuan Dari 160 lansia yang terdata tersebut, hanya sekitar 60 orang yang rutin datang ke posyandu lansia setiap bulannya dan didominasi oleh lansia perempuan. Berdasarkan hasil studi pendahuluan diketahui bahwa beberapa lansia tidak memanfaatkan posyandu lansia karena tidak dapat meninggalkan pekerjaan, kegiatan yang tidak menarik dan kurangnya informasi dari pemerintah setempat serta beberapa lansia yang mengganggap dirinya tidak sakit.Berdasarkan permasalahan diatas penliti tertarik untuk meneliti tentang faktor-faktor yang mempengaruhi pemanfaatan posyandu lansia di Dusun Karang Kulon Imogiri Bantul.

Penelitian ini bertujuan untuk mengetahui pengaruh demografi, struktur sosial, dukungan refrence group, persepsi sehat sakit dan persepsi kualitas pelayanan posyandu terhadap pemanfaatan posyandu di Dusun Karangkulon.

\section{BAHAN DAN METODE}

Jenis penelitian ini adalah penelitian deskriptif analitik dengan rancangan crossectional.Subjek penelitiannya adalah seluruh lansia yang terdata di posyandu lansia Dusun Karangkulon yang berjumlah 160 orang. Pengambilan sampel menggunakan tekhnik total sampling. Jumlah responden yang memenuhi kriteria inklusi dan eksklusi sebanyak 127 orang. Kirteria sampel adalah pria dan wanita 60 tahun keatas, mampu berkomunikasi, tidak mengalami demensia dan terdata di posyandu lansia Dusun Karangkulon. Penelitian ini dilaksanakan pada bulan Februari 2011 bertempat di Dusun Karang Kulon Bantul.

Variabel independen (bebas) dalam penelitian ini adalah terdiri dari data demografi (usia, jenis kelamin dan status perkawainan), status sosial (pendidikan dan pekerjaan), persepsi sehat sakit dan persepsi tentang kualitas pelayanan posyandu lansia dan dukungan refrence group. Perolehan data menggunakan kuesioner yang telah diuji validitas dan reliabelitas.Jenis data yang digunakan dalam penelitian ini adalah data primer. Sedangkan variabel dependen (terikat) adalah pemanfaatan posyandu lansia. Perolehan data menggunakan data skunder yang terdiri dari data kehadiran lansia ke posyandu lansia dan senam lansia. Data yang diperoleh kemudian dilakukan analisis menggunakan uji chi square dan uji regresi logistik dengan bantuan SPSS 16.0.

\section{HASIL DAN BAHASAN}

\section{Hasil Penelitian}

Hasil uji statsistik menggunakan uji chi square didapatkan bahwa karakteristik demografi yang terdiri dari umur, jenis kalmin dan status perkawainan. Umur lansia tidak berpengaruh terhadap pemanfaatan posyandu lansia. Hal tersebut dapat dilihat dari nilai $p=0,774$. Sedangkan untuk jenis kelamin diketahui bahwa terdapat pengaruh yang signifikan dengan pemanfaatan posyandu lansia. Hal tersebut dapat dilihat dari nilai $p=0,000$. Status perkawinan juga mempunyai pengaruh yang signifikan terhadap pemanfaatan posyandu lansia dengan nilai $p=0,018$. Variabel independen selanjutnya adalah status sosial yang terdiri dari pendidikan dan pekerjaan diketahui bahwa tidak terdapat pengaruh yang signifikan antara pendidikan dan pekerjaan dengan pemanfaatan posyandu lansia hal itu dapat dilihat dari nilai $p$ value untuk pendidikan adalah 0,059 dan pekerjaan adalah 1. Dukungan Refrence group tidak berpengaruh secara signifikan dengan pemanfaatan posyandu lansia sedangkan persepsi sehat sakit dan persepsi tentang kualitas pelayanan posyandu mempunyai pengaruh yang signifikan dengan nilai $p$ value masingmasing adalah 0,000.

Analisis multivariat dilakukan untuk menentukan variabel yang dominan dalam pola hubungan antara variabel bebas terhadap variabel terikat dengan menggunakan uji regresi logistik.Untuk menentukan variabel yang dominan terhadap pemanfaatan posyandu lansia.

Setelah dilakukan analisis didapatkan 2 variabel yang mempunyai nilai $p$ value $<0,05$ yaitu persepsi kualitas pelayanan posyandu $(p=0,025)$ dan persepsi tentang sehat dan sakit $(p=0,049)$. Sedangkan faktor yang paling berpengaruh adalah persepsi kualitas pelayanan posyandu dengan nilai $p=0,025$.

Berdasarkan pada tabel tersebut dapat dibuat sebuah model atau rumus untuk memprediksi variabel terikat yaitu sebagai berikut: 
Tabel 1. Hasil tabulasi silang dan uji chi square Faktor-Faktor yang Mempengaruhi Pemanfaatan posyandu lansia

\begin{tabular}{|c|c|c|c|c|c|c|c|}
\hline \multirow{3}{*}{ Variabel } & \multicolumn{4}{|c|}{ Pemanfaatan Posyandu lansia } & \multirow{2}{*}{\multicolumn{2}{|c|}{ Total }} & \multirow{6}{*}{$\begin{array}{c}0,082 \\
(0,774)\end{array}$} \\
\hline & \multicolumn{2}{|c|}{ Memanfaatkan } & \multicolumn{2}{|c|}{ Tidak Memanfaaatkan } & & & \\
\hline & $f$ & $\%$ & $f$ & $\%$ & $f$ & $\%$ & \\
\hline \multicolumn{7}{|l|}{ Umur } & \\
\hline $60-75$ th & 32 & 35,2 & 59 & 64,8 & 91 & 100 & \\
\hline$>75$ th & 11 & 30,6 & 25 & 69,4 & 36 & 100 & \\
\hline Jumlah & 43 & 33,9 & 84 & 66,1 & 127 & 100 & \\
\hline \multicolumn{8}{|l|}{ Jenis Kelamin } \\
\hline Laki-laki & 0 & 0 & 48 & 100 & 48 & 100 & 37,108 \\
\hline Perempuan & 43 & 54,4 & 36 & 45,6 & 79 & 100 & $(0,000)$ \\
\hline Jumlah & 43 & 33,9 & 84 & 66,1 & 127 & 100 & \\
\hline \multicolumn{8}{|l|}{ Status Perkawainan } \\
\hline Punya pasangan & 25 & 27,2 & 67 & 72,8 & 92 & 100 & 5,621 \\
\hline Tidak punya pasangan & 18 & 51,4 & 17 & 48,6 & 35 & 100 & $(0,018)$ \\
\hline Jumlah & 43 & 33,9 & 84 & 66,1 & 127 & 100 & \\
\hline \multicolumn{8}{|l|}{ Pendidikan } \\
\hline Dasar & 42 & 36,8 & 72 & 63,2 & 114 & 100 & 3,222 \\
\hline Menengah Atas & 1 & 7,7 & 12 & 92,3 & 13 & 100 & $(0,059)$ \\
\hline Jumlah & 43 & 33,9 & 84 & 66,1 & 127 & 100 & \\
\hline \multicolumn{8}{|l|}{ Pekerjaan } \\
\hline Bekerja & 38 & 33,9 & 74 & 66,1 & 112 & 100 & 0,000 \\
\hline Tidak bekerja & 5 & 33,3 & 10 & 66,7 & 15 & 100 & $(1)$ \\
\hline Jumlah & 43 & 33,9 & 84 & 66,1 & 127 & 100 & \\
\hline \multicolumn{8}{|c|}{ Dukungan Refrence Group } \\
\hline Tidak mendukung & 8 & 38,1 & 13 & 61,9 & 21 & 100 & 0,289 \\
\hline Dukungan sedang & 28 & 33,7 & 55 & 66,3 & 83 & 100 & $(0,865)$ \\
\hline Dukungan penuh & 7 & 30,4 & 16 & 69,6 & 23 & 100 & \\
\hline Jumlah & 43 & 33,9 & 84 & 66,1 & 127 & 100 & \\
\hline \multicolumn{8}{|l|}{ Persepsi Sehat sakit } \\
\hline Baik & 32 & 52,5 & 29 & 47,5 & 61 & 100 & 16,572 \\
\hline Buruk & 11 & 16,7 & 55 & 83,3 & 66 & 100 & 0,000 \\
\hline Jumlah & 43 & 33,9 & 84 & 66,1 & 127 & 100 & \\
\hline \multicolumn{8}{|c|}{ Persepsi kualitas pelayanan } \\
\hline Baik & 34 & 51,5 & 32 & 48,5 & 66 & 100 & 17,523 \\
\hline Buruk & 9 & 14,8 & 52 & 85,2 & 61 & 100 & $(0,000)$ \\
\hline Jumlah & 43 & 33,9 & 84 & 66,1 & 127 & 100 & \\
\hline
\end{tabular}

Tabel 2 Uji Regresi Logistic Faktor-Faktor Yang Mempangruhi Pemanfaatan Posyandu Lansia

\begin{tabular}{lccc}
\hline \multicolumn{1}{c}{ Variabel } & B & Exp (B) & p-value \\
\hline Tingkat pendidikan $(\mathrm{x} 1)$ & -1.985 & .137 & .095 \\
Persepsi sehat sakit $(\mathrm{x} 2)$ & 1.082 & 2.951 & .049 \\
Persepsi Kualitas Posyandu (x3) & 1.258 & 3.519 & .025 \\
Jenis Kelamin $(\mathrm{x} 4)$ & -21.031 & 0.000 & .997 \\
\hline Constanta $(\alpha)$ & & -1.085 & \\
\hline
\end{tabular}

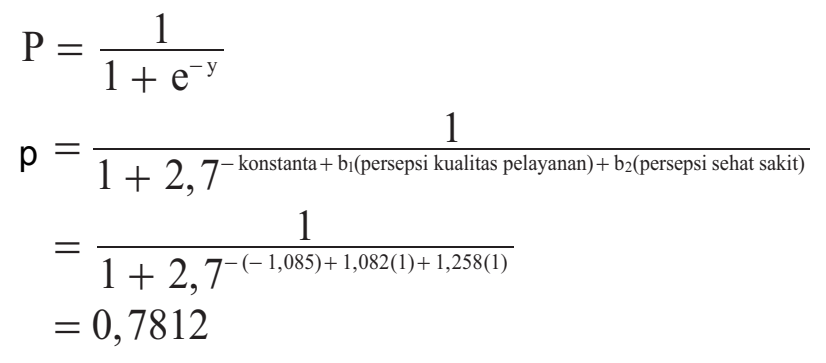

Artinya: Individu yang mempunyai persepsi buruk tentang kualitas posyandu lansia dan mempunyai persepsi buruk juga tentang sehat-sakit memiliki probabilitas untuk tidak memanfaatkan posyandu lansia sebesar $78,12 \%$.Untuk mengetahui kemungkinan (probabilitas) lansia yang tidak memanfaatkan pelayanan posyandu dapat dilihat pada Tabel 3. 
Tabel 3 Probabilitas Lansia Tidak Memanfaatkan Posyanndu Lansia

\begin{tabular}{cccc}
\hline No & $\begin{array}{c}\text { Persepi Kualitas } \\
\text { Pelayanan } \\
\text { posyandu }\end{array}$ & $\begin{array}{c}\text { Persepsi } \\
\text { Sehat-Sakit }\end{array}$ & Probabilitas \\
\hline 1 & Baik & Baik & $25,44 \%$ \\
2 & Baik & Buruk & $45,72 \%$ \\
3 & Buruk & Baik & $49,95 \%$ \\
4 & Buruk & Buruk & $78,12 \%$ \\
\hline
\end{tabular}

\section{Bahasan}

Berdasarkan hasil penelitain menunjukkan bahwa lansia yang terbanyak adalah umur 60-74 tahun $(71,7 \%)$ dengan rata-rata umur responden adalah 70,7 tahun. Tingginya rata-rata umur responden ini menggambarkan tingginya usia harapan hidup pada penduduk di Dusun Karangkulon. Menurut Dinas Kesehatan DIY (2008) menyatakan bahwa tingginya usia harapan hidup di daerah DIY merupakan representasi perbaikan dari banyak faktor antara lain ekonomi, pelayanan kesehatan, kualitas lingkungan dan sosiokulural masyarakat. Berdasarkan hasil analisis bivariat dengan chi square menujukkan bahwa umur tidak mempunyai pengaruh signifikan terhadap pemanfaatan posyandu lansia meskipun ada kencendrungan bahwa lansia yang tergolong elderly lebih banyak memanfaatkan posyandu lansia dibandingakan dengan kelompok old dan very old. Hal berbeda ditemukan oleh peneliti pada lansia di Dusun Karangkulon dimana sebagian besar penduduk lansia lebih dari 70 tahun relative tidak mengalami gangguan fisik bahkan masih produktive dan letak posyandu yang strategis serta mudah dijangkau sehingga lansia dengan umur berapapun cendrung memanfaatkan posyandu lansia.

Jenis kelamin berepengaruh terhadap pemanfaatan posyandu lansa dimana responden dengan jenis kelamin perempuan lebih memanfaatkan posyandu lansia Hal tersebut disebabkan karena perempuan lebih peka dan sensitif terhadap masalah kesehatan yang dideritanya sehingga perempuan lebih sering menggunakan fasilitas-fasilitas kesehatan untuk menjaga kesehatannya (Heniwati, 2006). Hal ini menyebabkan derajat kesehatan perempuan lebih bagus dari pada laki-laki yang akhirnya berpengaruh terhadap usia harapan hidup. Usia harapan hidup perempuan lebih tinggi dari pada laki-laki.

Berdasarkan struktur sosial diketahui bahwa pendidikan dan pekerjaan tidak berpengaruh terhadap pemanfaatan posyandu lansia. Hal tersebut menujukkan bahwa pengetahuan dan informasi tentang kesehatan tidak selalu didapatkan dari pendidikan formal. Terdapat berbagai macam sumber informasi untuk dapat meningkatkan pengetahuan misalnya radio, tv, kader maupun refrence group. Jika dilihat dari data yang ada bahwa mayoritas pekerjaan lansia adalah tani dan membatik.Pekerjaan tersebut bersifat tidak mengikat seperti guru, pegawai atau pedagang yang memerlukan waktu kerja pagi sampai siang hari.Terutama membatik, bisa dikerjakan pada kapan saja sehingga lansia mempunyai waktu luang untuk memanfaatkan posyandu lansia.

Dukungan refrence group tidak berpengaruh terhadap pemanfaatan posyandu lansia Hal ini dimungkinkan karena sebagian besar lansia yang memanfaatkan posyandu adalah karena kesadaran pribadi tanpa ada paksaan ataupun intervensi atau dukungan dari refrence gruop. Hal ini bertentangan dengan pendapat $\mathrm{WHO}$ (1984) seperti yang dikutip oleh Notoatmodjo (2003) yang menyatakan bahwa perilaku seseorang sedikit banyak dipengaruhi oleh orang-orang yang dianggap penting. Apabila seseorang dianggap penting untuknya maka apa yang ia katakan atau perbuat cendrung untuk dicontoh.

Persepsi sehat sakit mempunyai pengaruh terhadap pemanfaaatan posyandu lansia. Hasil penelitian ini konsisten dengan apa yang diungkapkan Notoatmodjo (2003) yang menyatakan bahwa persepsi sehat sakit mempengaruhi seseorang memanfaatkan pelayanan kesehatan, jika persepsi masyarakat sama dengan persepsi penyedia pelayanan kesehatan maka masyarakat akan cendrung memanfaatkan pelayanan kesehatan, begitu juga sebaliknya.

Umumnya lansia yang memanfaatkan posyandu adalah lansia yang mempunyai persepsi baik terhadap kualitas posyandu lansia. Hasil penelitian ini menunjukkan bahwa kualitas pelayanan merupakan suatu hal yang penting karena seseorang yang merasa puas akan mau memanfaatkan pelayanan kesehatan kembali. Hasil ini juga sesuai dengan pendapat Pohan (2007) yang menyatakan pandangan masyarakat mengenai kualitas pelayanan merupakan hal yang penting. Menurut Walgito (2002) menyatakan bahwa persepsi terjadi melalui beberapa sub proses yaitu objek menimbulkan stimulus dan stimulus mengenai alat indra atau reseptor. Stimulus yang diterima oleh alat indra diteruskan oleh syaraf sensoris ke otak yang disebut sebagai proses fisiologis. Kemudian terjadilah proses diotak sehingga individu menyadari apa yang dilihat, didengar atau diraba. Proses ini disebut sebagai proses psikologis. Jadi proses akhir dari terjadinya persepsi adalah individu menyadari tentang adanya stimulus yang diterima melalui alat indra dan merupakan proses dari hasil persepsi yang sebenarnya. Setelah itu individu akan memberikan respon dari persepsi dari berbagai respon yang diterima dalam berbagai bentuk. 
Dalam penelitian ini, bentuk persepsi yang baik mempunyai respon yang baik pula yaitu ada kecendrungan bahwa lansia yang mempunyai persepsi yang baik pada kualitas pelayanan dan sehat sakit akan berespon dengan memanfaatkan posyandu lansia.

\section{Simpulan}

Ada pengaruh signifikan jenis kelamin, status perkawinan, persepsi sehat sakit dan persepsi kualitas pelayanan posyandu lansia sedangkan Umur, pendidikan, pekerjaan dan refrence group tidak berpengaruh signifikan terhadap pemanfaatan posyandu lansia di Dusun Karangkulon. Faktor yang paling berpengaruh adalah persepsi tentang kualitas pelayanan posyandu dilanjutkan dengan persepsi tentang sehat-sakit.

\section{Saran}

Kader dan petugas kesehatan diharapkan dapat meningkatkan kualitas posyandu dengan memfasilitasi dan mendukung semua kegiatan yang ada di posyandu lansia sehingga posyandu dapat berjalan sebagaimana yang diharapkan. Selain itu petugas puskesmas juga harus lebih giat memberikan promosi kesehatan terhadap lansia agar persepsi lansia tentang sehat dan sakit menjadi lebih baik.

\section{Rujukan}

Abraham. C. 1997. Psikologi Sosial Untuk Perawat. Jakarta: EGC.

Affandi, B.1997. "Masalah Kesehatan Pada MasaMasa Menopause", dalam Medika No 9 Tahun XXIII.

Arikunto, Suharsimi. 2006. Prosedur Penelitian Suatu Pendekatan Praktik. Jakarta: Rineka Cipta.

Cahyati, Dewi. 2006. "Faktor-Faktor yang Mempengaruhi Pemanfaatan Posyandu Lansia di Desa Trihanggo Wilayah Kerja Puskesmas Gamping II Sleman Yogyakarta.UGM. Tidak diterbitkan

Bondan.Palestin. 2008. "Perawatan Restoratif Untuk Mencegah Gagal-Pulih Pada Lanjut Usia di Masyarakat" dalam http://bondankomunitas. blogspot.com/2008/06/perawatan-restoratifuntuk-mencegah.html" Tanggal Akses 23 Desember 2010, pukul 11:00.

Dahlan. M. Sopiyudin. 2009. Statistik Untuk Kedokteran Dan Kesehatan. Jakarta: Salemba Medika.

Darmojo, Bodhi. 2004. Buku Ajar Geriatri. Jakarta: Fakultas Kedokteran UI.
Dinas Kesehatan DIY. 2008. Hasil Riset Dasar Kesehatan 2007. Yogyakarta: Dinas Kesehatan DIY.

Dinas Kesehatan DIY. 2008. Profil Kesehatan Provinsi DIY 2008. Yogyakarta: Dinas Kesehatan DIY.

Departemen Kesehatan R.I. 2003. Pedoman Pemantauan dan Penilaian Program Kesehatan Usia Lanjut Bagi Petugas Kesehatan. Jakarta: Bina Kesehatan Masyarakat Departemen Kesehatan R. I.

Departemen Kesehatan R.I. 2003. Pedoman Puskesmas Santun Usia Lanjut Bagi Petugas Kesehatan dan Perawatan Kesehatan Usia Lanjut di Rumah. Jakarta : Departemen Kesehatan R. I.

Departemen Kesehatan R.I. 2005.Pedoman Pembinaan Kesehatan Usia lanjut Bagi Petugas Kesehatan.Jakarta : Departemen Kesehatan R. I.

Departemen Kesehatan R.I. 2006. Saya Bangga Menjadi Kader Posyandu. Jakarta: Bina Kesehatan Masyarakat Departemen Kesehatan R. I.

Erfendi.2008."Pengelolaan Posyandu lansia" dalam www.erfendi-blogspot.com. Tanggal Akses 17 Desember 2010, pukul 11:20 WIB.

Hardywinoto, Setiabudhi.2007. Panduan Gerontologi. Jakarta:Pustaka Utama.

Hasibuan, Wirdasari dan Ismayadi. 2006. "Hubungan Program Pelayanan Posyandu Lansia Terhadap Tingkat Kepuasan Lansia Di Daerah Binaan Puskesmas Darussalam Medan" dalam jurnal Keperawatan Rufaidah Sumatera Utara, Volume 2 Nomer 1, tahun 2006.

Heniwati. 2008. " Faktor-Faktor yang Mempengaruhi Pemanfaatan Pelayanan Posyandu Lansia di Wilayah Kerja Puskesmas Kabupaten Aceh Timur" Tesis Mahasiswi Sekolah Pascasarjana Universitas Sumatera Utara.Tidak diterbitkan.

Hidyat, A, Aziz Alimul.2008. Riset Keperawatan dan Teknik Penulisan IImiah.Jakarta : Salemba Medika.

Machfoedz, Ircham. 2007. Statistika Induktif. Yogyakarta: Fitramaya.

Machfoedz, Ircham. 2009. Metodologi Penelitian. Yogyakarta: Fitramaya.

Machfoedz, Ircham. 2010. Cara Membuat Kuesioner dan Panduan Wawancara. Yogyakarta: Fitramaya.

Mangoenprasodjo. 2005. Mengisi Hari Tua Dengan Bahagia. Jakarta : Pradipta Publishing.

Maramis, W.F. 2004. Catatan IImu Kedokteran Jiwa. Surabaya: Airlangga University press..

Mubarok, dkk. 2006. Ilmu Keperawatan Komunitas 2. Jakarta: Sagung Seto. 
Notoatmodjo, S. 2003. Pendidikan dan Perilaku Kesehatan.Jakarta : Rineka Cipta

Notoatmodjo, S. 2007. Metodologi Penelitian Kesehatan. Jakarta : Rineka Cipta.

Nugroho, W. 2000.Keperawatan Gerontik edisi 2.Jakarta : EGC.

Ozi. 2010. "Indonesia Targetkan UHH 72 Tahun" dalam http://www.globalfmlombok.com/content/ indonesia-targetkan-uhh-capai-72-tahun. Tanggal Akses 15 Desember, Pukul 11:30

Pohan, I. 2007. Jaminan Mutu Pelayanan Kesehatan. EGC : Jakarta

Pujiono. 2009. "Faktor-Faktor yang Berhubungan dengan Pemanfaatan Posyandu Lansia di Desa Jetis Kecamatan Karanganyar Kabupaten Grobogan" Tesis Mahasiswa Program Pascasarjana Promosi Kesehatan Universitas Diponogoro.

Saryono. 2009. Metodologi Penelitian Kesehatan. Yogykarta: Mitra Cendikia.

Sugiyono. 2007. Statistika Untuk Penelitian. Bandung: Alfabeta.

Rahayu, S. 2006 "Faktor-Faktor yang Mempengaruhi Ketidaktifan Lansia ke Posyandu Lansia di Puskesmas Cebongan Salatiga.UGM. Tidak Diterbitkan.
Ritonga. 2007" Umur Harapan Hidup Penduduk Global” dalam http://ritonga.blogspot.com “ tanggal Akses 9 Desember 2010, Pukul 09:00 WIB.

Noviana, Uki. 2008. "Faktor-Faktor Yang Mempengaruhi Keluarga Dalam Pengambilan Keputusan Pemanfaatan Pelayanan Kesehatan Puskesmas Di kabupaten Sleman Yogyakarta" Skripsi Mahasiswi Fakultas Kedokteran Universitas Gajah Mada.

Walgito. 2002. Psikologi Sosial Suatu Pengantar Edisi Revisi. Yogyakarta: Andi Offset.

, 2010. “Sensus Penduduk Indonesia 2010" dalam http://id.wikipedia.org/wiki/Sensus_Penduduk_ Indonesia_2010. Tanggal Akses 10 Desember 2010, Pukul 19:30 WIB.

, 2010. “Jumlah Penduduk DIY Berdasarkan Hasil Sensus 2010" dalam www.bps.go.id/diy . Tanggal Akses 10 Desember 2010, Pukul 20:00 WIB.

,2009. “Jumlah Lansia Di Indonesia Meningkat 11,34\%" dalam http://bataviase.co.id/detailberita-10423665. html. Tanggal Akses 9 Desember 2010, pukul 10:20 WIB.

, 2009. " Usia Harapan Hidup Penduduk Indonesia" dalam http://data.menkokesra.go.id/ content/usia-harapan-hidup-penduduk-indonesia . Tanggal Akses 15 Desember 2010, Pukul 10:45 WIB 